,
• бюк
ернопільський н ціон льний пед гогічний університет
імені олодимир н тюк,
вул. . ривонос , 2, м. ернопіль, 46027, кр їн

озглянуто проблеми, спричинені неконтрольов ним н в нт женням н урочище ервоне ліщицького р-ну, ернопільської обл. й окреслено н прями їхнього можливого вирішення. творення екологічної стежки обгрунтов но як дієвий інструмент для оптиміз ції рекре ційного використ ння території т підвищення екологічної культури н селення. пис но м ршрут проектов ної екостежки “ журинський к ньйон” з рекоменд ціями щодо бл гоустрою т інформ ційного н сичення.

лючові слов : екологічн освіт, екологічн стежк, екотуризм, рекре ція, туризм.

ст нніми рок ми розвиток внутрішнього туризму т популяриз ція регіону ереднього одністер'я зумовили зн чне рекре ційне н в нт ження н окремі об'єкти т регіон з г лом. кий неконтрольов ний процес посилюється низьким рівнем екологічної культури рекре нтів і в сукупності спричиняє дегр д цію унік льних л ндш фтів т урочищ, появу стихійних сміттезв лищ. е зд тні вирішити н явну з грозливу ситуцію і поодинокі екологічні кції, що їх проводять гром дські орг ніз ції, які перев жно борються вже з н слідк ми у вигляді сміття в місцях відпочинку, не з першопричин ми т ких процесів. утворенням н ціон льного п рку “ ністровський к ньйон” н ведені проблеми н був ють ще більшої в ги.

я територія є одним з н йяскр віших прикл дів швидкого безконтрольного розвитку туризму в окремому урочищі, що призвело до низки екологічних т соці льних проблем. продовж п'яти-семи років урочище ервоне ст ло однією з н йбільш відвідув них місцин ернопільської обл. формув л ся х отичн мереж стоянок, доріг, стежок, які з'єднують околиці сіл ирків т горяни з прив бливими об'єкт ми, розт шов ними непод лік. ор з більше рекре ційне н в нт ження спричиняє дегр д цію т руйнув ння, без перебільшення, унік льних п м'яток природи т історії. ому першочерговим з вд нням ст є оптиміз ція рекре ційного використ ння території т перерозподіл потоку відпочив льників причому вирішити ці з вд ння можливо лише з соб ми регульов ного й обгрунтов ного розвитку туризму в поєдн нні з підвищенням екологічної культури і свідомості рекре нтів.

ит ння рекре ційного використ ння природоз повідних територій н йглибше досліджене . ижовою [6, 7]. роблему охорони т р ціон льного використ ння природоз повідного фонду кр їни ктивно висвітлює . етьм н [3]. ністерський регіон т , зокрем , його природо-з повідні території опис ні кр єзн вцем . йковським [4].

днією з н йв жливіших форм р ціон льного природокористув ння, т кож основою для формув ння екологічної культури н селення є екологічн стежк .

(C) бюК ., 2011 
кологічн стежк - це спеці льно обл дн ний м ршрут, що проходить через різні екологічні системи т інші природні об'єкти, рхітектурні п м'ятки, які м ють естетичну, природоохоронну т історичну цінність; н екологічній стежці відвідув чі отримують усну (з допомогою екскурсовод ) бо письмову (стенди, ншл ги тощо) інформ цію про ці об'єкти. рг ніз ція екологічних стежок - одн з форм вихов ння екологічного мислення і світогляду. різних кр їн х їх н зив ють по-різному: пішохідні доріжки, треки, туристичні стежки, пейз жні стежки, зелені шляхи т ін.

зву “екологічн стежк" треб розуміти як “вивчення природи” і як “н вч ння природою”. ншими слов ми, мет створення стежки - н вЧ ння і вихов ння відвідув чів.

одного боку, з вд нням стежки є своєрідний “природозн вчий лікнеп”, тобто розширення кругозору екскурс нтів стосовно об'єктів, процесів і явищ довкілля, з іншого, - н вчити б чити, поміч ти різні прояви нтропогенних чинників, які можн спостеріг ти в зоні м ршруту стежки, т вміти комплексно оцінюв ти ці результ ти дії людини н довкілля.

ретє, зрештою, провідне з вд ння екологічних стежок, зокрем , в меж х н ціон льного п рку, - сприяти вихов нню екологічної культури поведінки особистості як ч стини з г льної культури вз ємин людей один з одним і ст влення людини до природи [1] .

кий з сіб екологічної освіти в р зі ктивного висвітлення $\mathrm{T}$ координ ційної роботи з туропер тор ми і голов ми селищних р д допоможе подол ти к т строфічну ситу цію в регіоні.

. ижов виділил три основні умови для вибору м ршруту екостежки: прив бливість, доступність т інформ тивність [6, с. 12]. роектов н стежк “ журинський к ньйон” повністю відповід є т ким вимог м.

оступність. оч ток проектов ної екостежки є н околиці с. ирків ліщицького p-ну. ідст нь до обл сного центру - 120 км, до р йцентру - 25 км, діст тися сюди можн зручним сф льтов ним шляхом 3 кільк годин. йближч зупинк гром дського втотр нспорту з ернополя н ороденку т нятин розт шов н 34 км, 310 км є з лізничн ст нція орвулинці - це д є змогу відвід ти стежку с модіяльним груп м рекре нтів без вл сного тр нспорту. ілянк ернопіль- горяни н сичен різном нітними історико- рхітектурними об'єкт ми: икулинецький з мок, еребовлянський $з$ мок, комплекс п м'яток ст рого ортков, гільницький п л ц т ін. я обст вин сприятиме орг ніз ції нових туристичних м ршрутів, основним об'єктом яких ст не проектов н екологічн стежк .

рив бливість проектов ної екостежки поляг є в поєдн нні н комп ктній території унік льного комплексу цік вих історико- рхітектурних, гідрологічних, бот нічних, зоологічних, геологічних об'єктів з винятковою м льовничістю н вколишніх л ндш фтів. ергув ння різних 3 тем тикою об'єктів робить м ршрут контр стним т н сиченим.

нформ тивність. я екологічн стежк вирізняється 3-поміж інших туристичних м ршрутів м ксим льно можливим відобр женням геологічних, л ндш фтних, бот нічних т історичних особливостей території, т кож високою зд тністю з довольняти пізн в льну потребу рекре нтів. жливе з вд ння в цьому р зі покл д ють н інформ ційні стенди т вк зівники, які не просто допоможуть рекре нту зорієнтув тися н місцевості, й озн йомлять з особливостями кожного об'єкт . роте, вр ховуючи обмежену площу стендів, дод тковим інформ ційним інструментом повинні ст ти путівники т буклети.

огляду н всі передумови доцільно створити с ме еколого-пізн в льну стежку. 
еред поч тком створення екологічної стежки в меж х природо-з повідної території необхідно вивчити не лише н явні природні умови т цік ві об'єкти регіону, й х р ктер рекре ційного використ ння, зокрем , періоди н йбільш ктивного відвідув ння, специфіку груп відвідув чів т ін. ме від цих чинників з лежить призн чення, простяг ння т підбір типу стежки, як якн йліпше відповід є цим умов м [6, с. 12].

ериторію проектов ної екологічної стежки “ журинський к ньйон” н йбільше відвідують у теплу пору року. ік рекре ційного н в нт ження прип д є н тр вень-серпень. оодинокі групи туристів відвідують урочище в період з жовтня по березень.

ону проектов ної екологічної стежки “ журинський к ньйон” донед вн ктивно відвідув ли екскурс нти орг нізов них груп тернопільських і чернівецьких туропер торів (ост нніми рок ми територія поступово втр ч є прив бливість для цієї к тегорії).

ч сники т ких подорожей з звич й не $з$ вд ють зн чної шкоди довкіллю, це зумовлено присутністю гід -провідник , який стежить 3 порядком у кожній групі т ч совим обмеженням перебув ння кожної групи н м ршруті. опри це все ж необхідно дод тково провести зустрічі з провідник ми т екскурсовод ми обл сних туристичних фірм т зобов'яз ти їх н голошув ти н необхідності дотрим ння порядку н території екостежки.

нш $\mathrm{K}$ тегорія рекре нтів у цьому урочищі - уч сники різном нітних т борів, орг нізов них релігійними гром д ми, н вч льними з кл д ми, гром дськими орг ніз ціями т ін. они з лиш ються в урочищі н період від двох до десяти днів. ільшість 3 них $з$ вд $є$ непопр вної шкоди окремими нес нкціонов ними рубк ми, з готівлею дров, витоптув нням тр в тощо. иняток ст новлять т бори, з кл дені орг ніз ціями “ л ст” т “рист л”, їхні уч сники сл вляться високим рівнем екологічної свідомості й ретельно прибир ють г лявини н з пл ві річки журин т прилеглі території. оцільно н 3 верш льному ет пі формув ння екологічної стежки перед ти усім орг ніз тор м т ких т борів пр вил перебув ння н території т зобов'яз ти стежити з їхнім дотрим нням.

е одн к тегорія рекре нтів, які інтенсивно відвідують цю територію, - жителі н вколишніх сіл ирків, горяни, стечко, олоне, овсте т р йонного центру ліщики. р ктерною рисою цієї к тегорії є низький рівень їхньої екологічної культури. плинути н т ких рекре нтів можн двом шлях ми: перший - провести зустрічі 3 керівник ми місцевих гром д (голов ми сільр д, священик ми т вчителями) - с ме вони зможуть безперешкодно донести інформ цію про пр вил поводження н території екостежки т н ціон льного п рку з г лом; другий - м ксим льно з луч ти місцевих школярів до волонтерських робіт з бл гоустрою, укріплення стежок, виготовлення елементів вк зівників і стендів. е не лише д сть змогу зн чно скоротити термін викон ння робіт, й послугує винятково дієвим інструментом екологічної освіти.

од тковим ресурсом у р зі формув ння т бл гоустрою екостежки можуть бути студенти туристичних спеці льностей обл сного центру, дже н вч льні прогр ми кр єзн вств $\mathrm{T}$ екотуризму повинні вирізнятися 3-поміж інших отрим нням відповідних пр ктичних зн нь з підвищенням екологічної культури т свідомості [7, с. 104].

ід ч с пл нув ння екостежки доцільно визн чити допустиме рекре ційне н в нт ження для неї, причому м ємо н ув зі не просто кількість рекре нтів н одиницю ч су і н одиницю площі, весь комплекс рекре ційного впливу н територію [6, с. 50]. роведені спостереження впродовж ктивного рекре ційного сезону (тр вень-вересень) свідч ть, що в середньому у будні територію екостежки відвідує три групи до десяти осіб кожн впродовж дня, у вихідні ж ця кількість сяг є 25-30 груп у день, у неділю до 
них ще долуч ються жителі н вколишніх сіл, тобто ще 100 осіб у день. день середня сум рн кількість рекре нтів ст новитиме 850 осіб, тобто впродовж тр вня-серпня ця цифр сягне 17 тижнів*850 осіб=14 450 осіб. т ке н в нт ження можн опир тися н поч ткових ет п х створення т функціонув ння екостежки, провівши впродовж одного туристичного сезону моніторинг усіх ділянок м ршруту i, з лежно від отрим них результ тів, н д лі коригув ти потік рекре нтів бо ж розробляти т ре лізовув ти комплекс 3 ходів з підвищення стійкості стежки до рекре ційного н в нТ ження.

ротяжність проектов ного м ршруту - близько 6 км. с проходження м ршруту 4 год (див. рисунок).

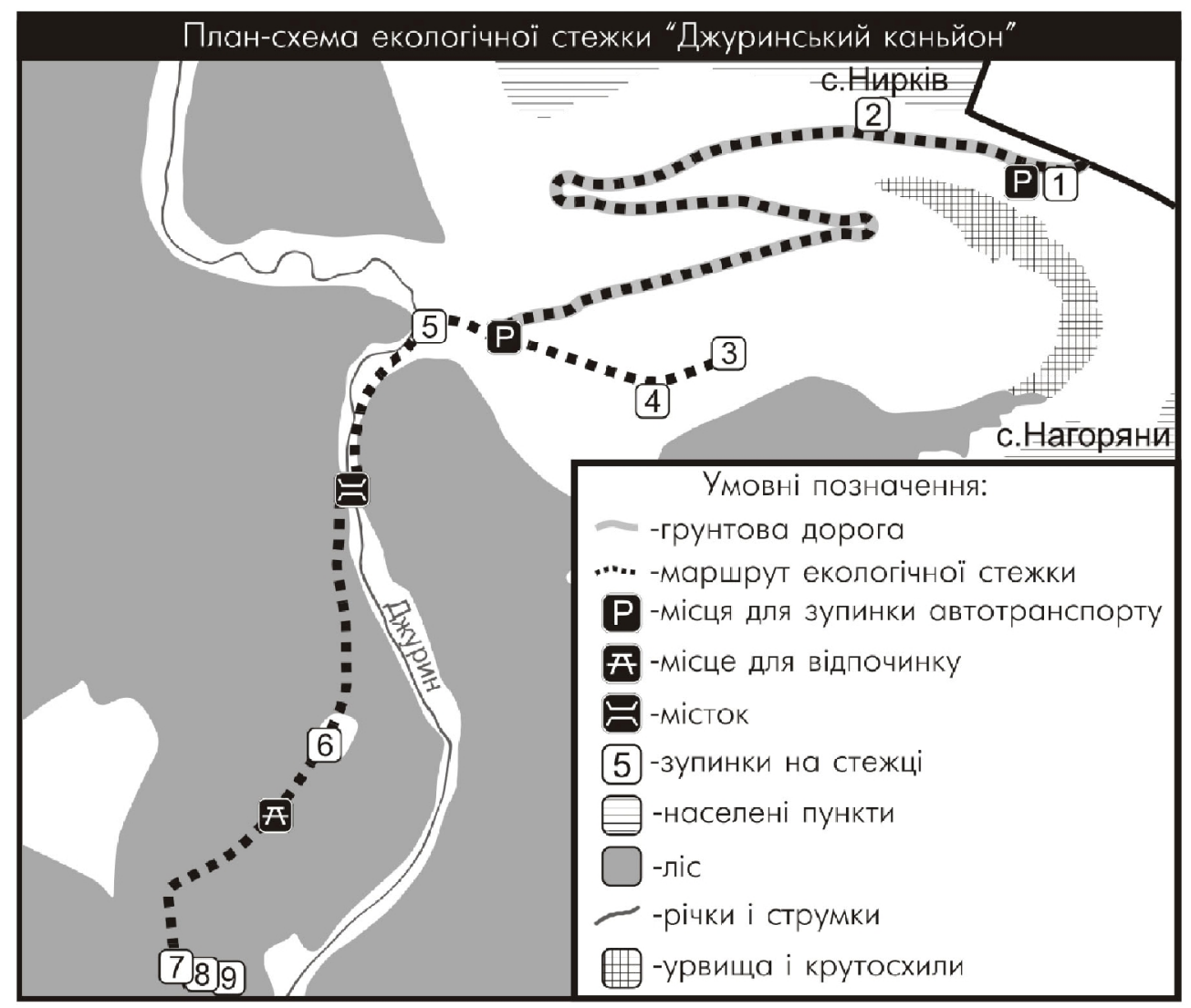

л н-схем екологічної стежки “ журинський к ньйон”.

очк 1. озпочин ється екологічн стежк “ журинський к ньйон” н околиці c. ирків н брівці глибокого к ньйону р. журин. ут з сф льтов ного шляху зверт є вниз грунтов дорог . відси відкрив ється м льовнич п нор м к ньйону з двом 3 мковими б шт ми внизу. оцільно тут розмістити вхідний стенд, т к зв ні ворот стежки, з нього туристи можуть отрим ти інформ цію про протяжність м ршруту, основні природні т історико- рхітектурні п м'ятки і пр вил поведінки; т кож можн розміщу- 
в ти опер тивну інформ цію стосовно певного сезону, відомості про скл дні ділянки, попередження стосовно питної води, кліщів, ком рів т ін. кий стенд легко помітити з сф льтов ної дороги. іля нього треб розширити грунтову дорогу, щоб полегшити роз'їзд зустрічного тр нспорту. лі дорог зверт $є$ пр воруч схилом.

очк 2. ступн зупинк біля руїн м взолею онінських, зведеного н поч тку

ст. 1835 р. вл сниця місцевого м єтку елен онінськ 3 мовил у д нського скульптор . орв льдсен скульптурний н дгробок н могилу дітей, його виготовили 3 сім років і ще рік вист вляли у рш ві. середині ст. . озницький відшук в н дгробок у поруйнов ному м взолеї, нині він зберіг ється у ьвівській г лереї мистецтв.

ов зупинк вже в долині к ньйону, непод лік входу н територію дитячого т бору “ ом шк”. орог сюди в з довільному ст ні, тому н поч ткових ет п х функціонув ння не потребув тиме зн чних змін, окрім поліпшення дренув ння окремих ділянок. оцільно розширити т впорядкув ти стихійний м йд нчик для втомобілів і розмістити поряд ще один стенд з пр вил ми поведінки н екологічній стежці. ут розпочин ється пішохідн ч стин м ршруту.

очк 3. ступний об'єкт - руїни з мку, що з кільк сот метрів н невеликому п горбі. ерше поселення тут з кл дене ще у ст., пізніше знищене монголо-т т р ми.

V ст. литовсько-руські князі орі товичі збудув ли н цьому місці дерев'яний 3 мок, який $з$ дв століття теж був повністю зруйнов ний. поч тку XVII ст. вл сник львівський к штелян - нилович звів муров ний чотирикутний з мок 3 веж ми н кут х, оточений оборонним муром із в'їзною бр мою. поч тку ст. роль онінський звелів розібр ти дві з мкові вежі й ч стину з мку, м тері ли використ ти н спорудження нового п л цу. ізніше дві з лишені вежі перебудув в його син, зробивши їх вищими, у псевдоренес нсному стилі. л ц був оточений кр сивим л ндш фтним п рком з фонт ном. ві світові війни призвели до руйнув ння споруди, довершив іiі один з р дянських голів колгоспу с. ирків, який розпорядився з з мкових мурів збудув ти свин рник.

очк 4. епод лік від з мку - костел ознесіння іви. ведений у $\mathrm{V}$ ст. онині збереглися рештки д вніх фресок н стін х. мок і костел перед ні у вл сність ернопільської єп рхії , тож доцільно попередньо дет льно узгодити з ними можливості з лучення цих об'єктів до екологічної стежки.

очк 5. е один пункт м ршруту розт шов ний з кільк десятків метрів, гучний шум його чутно через усю долину. журинський водосп д $є$ н йвищим водосп дом рівнинної території кр їни, висот його сяг є 16 м [4, с. 22]. p с велетенського водосп ду прив блює безліч рекре нтів з усіх куточків кр їни. я п м'ятк м є д внє т все ж рукотворне походження - у $\mathrm{V}$ ст. турки перекоп ли вузький перешийок звивистого ме ндру р. журин, ч стково осушили ст ре русло, знизивши цим оборонну зд тність твердині. о 50-х років ст. н водосп ді функціонув в водяний млин, пізніше - невеличк . спуску від м йд нчик , біля водосп ду униз необхідно обл штув ти східці з перил ми. оцільно зробити т к зв ні покрокові східці, використ вши плитки місцевого червоноколірного девонського пісковику. і сходинки іде льно впишуться у н вколишній л ндш фт і т к конструкція не буде ускл днюв ти поверхневий стік, і їі не розмив тимуть дощові потоки. відси стежк проляг є з пл вною г лявиною до невеличкої кл дки - обл штув ти її в рто, використ вши стовбур дерев зі сколотою поверхнею. 
лі м ршрут проектов ної екостежки проляг тиме грунтовою дорогою, як пл вно підійм ється вгору з лісненим схилом р. журин.

очк 6. ергову зупинку н м ршруті в рто зробити н невеличкій г лявині н місці д вньої вирубки. цій місцині можн озн йомитися з ф уною т флорою н вколишніх лісів, інформ ція про них розміститься н стенді. ут можн поб чити вус ч мускусного, жук -оленя, копр місячного, н д різнотр в'ям н узліссі проліт ють б рвисті м х они т под лірії. рто попередити рекре нтів, що н цій ділянці дороги ч сто тр пляються вужі, і н голосити н тому, що вони цілком безпечні для людини. епод лік можн розмістити л вочки-колоди для відпочинку.

ісов дорог знову йде вгору, з десять метрів до виходу дороги н велику г лявину-вирубку потрібно звернути вліво. цьому місці треб вст новити вк зівник.

очк 7. тежк з кільк сот метрів приведе до лісового джерел . трумок від нього перетин є тр вертинову скелю т зрив ється униз. кр ю скелі доцільно обл штув ти оглядовий м йд нчик з міцними поручнями. відси відкрив ється м льовнич п нор м долини р. журин т н вколишніх лісових м сивів.

очк 8. о н ступного об'єкт потрібно зійти вниз по південному кр ю скелі. ут і д лі вниз до підніжжя скелі необхідно обл штув ти вже зг дув ні покрокові східці, оскільки крутість схилу т коріння дерев зн чно ускл днюють спуск. скелі н місці невеликої природної порожнини вируб но невеличкий грот-келію розмір ми 2,5х2,0х2,3 м, орієнт ція північ-південь. клепіння ов льне зі слід ми вирубув ння. ервинн вхідн ч стин грот зруйнов н . іля з хідної стіни розт шов н нтропоморфн $б$ рельєфн скульптур висотою 1 м з рук ми біля грудей. ирин скульптури -40 см, вон стоїть н вируб ній к м'яній полиці. іля ідол зн йдено три фр гменти в пнякової скульптури, викон ної дет льніше. ісцеві жителі т н уковці трив лий ч с ув ж ли фігуру скульптурою св. нуфрія, витес ною відлюдником, який прожив в у гроті до 1939 р., проте історик . ртюх стверджує, що це д вній язичницький божок [2, с.144].

очк 9. лі зупинк біля підніжжя скелі, поряд з кр сивим водосп дом “ івочі сльози”. цьому пункті н стенді необхідно розмістити інформ цію про тр вертинові скелі т їхнє поширення, оскільки місцин яскр во ілюструє формув ння тр вертинів. ід водосп дом у поток х води росте водорість вошерія, непод лік - з рості листовик сколопендрового. ілянк під водосп дом вкрит тр вертиновим гр вієм, їі постійно зволожують води водосп ду, тож в рто обл штув ти т к зв ну лежнівку у вигляді дощ ного н стилу, дещо піднятого н д поверхнею. основу можн використ ти покришки від коліс - вони довговічні і стійкі до н в нт жень. кий м тері л є екологічно безпечним $з$ вдяки зн чній хімічній інертності м тері лу [6, с. 50].

одосп д ст не ост ннім об'єктом н цій екологічній стежці. відси відвідув чі можуть повернутися до втобус бо ж зійти лісовою дорогою до с. стечко.

тже, орг ніз ція в урочищі ервоне екологічної стежки д сть змогу оптимізув ти рекре ційне використ ння цінних об'єктів і перерозподілити потік рекре нтів з соб ми регульов ного, н уково обгрунтов ного туризму в поєдн нні з підвищенням екологічної культури туристів. $\quad \mathrm{K}$ екостежк $€$ н йзручнішою системою екологічної освіти і зд тн вплинути н низку проблем, пов'яз них з неконтрольов ним рекре ційним використ нням урочищ . ирішити ж т ку проблему можн лише створенням у регіоні мережі екостежок. 
1. кон кр їни “ ро природно-з повідний фонд кр їни” N 1287-XIV від 14.12.99. т. 20-22.

2. ртюх . зичництво т р нне християнство ст род вньої личини / . ртюх. ьвів : полом. 2006. $200 \mathrm{c}$.

3. етьм н . . екре ційн діяльність у меж х природо-з повідного фонду // повідн спр в в кр їні / з г. ред. . . родзинського, . . теценк / . . етьм н. . : еогр фік , 2003. . 162-175.

4. йковський . . ністровський к ньйон: риродозн вчий н рис / . . йковський. ьвів : меняр, 1981. $64 \mathrm{c.}$

5. ерняк . . . ідкісні т зник ючі рослини ернопільщини з ервоної книги кр їни / . . ерняк. ернопіль : вч. книг - огд н. 2008. 224 с.

6. ижов . . роп в г рмонии с природой: борник российского и з рубежного опыт по созд нию экологических троп / . . ижов . . . : . лент, 2007. 176с

7. ижов . . екре ционный л ндш фт к к объект экологического обр зов ния // уризм и рекре ция : фунд мент льные и прикл дные исследов ния. p. IV междун р. н уч.-пр кт. конф./ . . ижов . . . и и лог культур, 2009. .102-106.

\title{
ECOLOGICAL PATH "DZHURYN CANYON" ELABORATION AS A MEAN OF RECREATION USAGE OPTIMIZATION IN CHERVONE ZONE
}

\author{
L. Babyuk \\ Volodymyr Gnatyuk National Pedagogical University of Ternopil, \\ M. Kryvonos, 2, UA-46027 Ternopil, Ukraine
}

The scope of the work is a range of problems connected with increasing loading in Chervone zone (Zalishchytskyi region, Ternopilska oblast') and the ways of their solution. Ecological path construction is considered to be an effective mean of recreation usage optimization and ecological cultural advance. The work gives description of the whole rout of ecological path "Dzhuryn canyon" and recommendations for its arrangement and information filling.

Key words: ecological education, ecotourism, ecotrail, recreation, tourism.

$$
\text { - бюк }
$$

ернопольский н цион льный пед гогический университет имени л димир н тюк, ул. . ривонос , 2, г. ернополь, 46027, кр ин

ссмотрено проблемы, вызв нные н р ст ющей неконтролиров нной н грузкой н урочище ервоное лещицкого р-н, ернопольской обл. и очерчено н пр вления для их возможного решения. озд ние экологической тропы обоснов но к к действенный инструмент для оптими3 ции рекре ционного использов ния территории и повышения экологической культуры н селения. пис но м ршрут проектируемой экотропы “ журинский к ньон” с рекоменд циями по бл гоустройству и информ ционным н полнением.

лючевые слов : экологическое обр зов ние, экологическ я троп , экотуризм, рекре ция, туризм.

т ття н дійшл до редколегії 07.09.2010 рийнят до друку 16.11.2010 